\title{
Mathematics Teaching Anxiety Scale: Construction, Reliability and Validity
}

\author{
Vesile Alkan (iD) 1,*, Tolga Coşguner ${ }^{1}$, Yücel Fidan ${ }^{1}$ \\ ${ }^{1}$ Pamukkale University, Faculty of Education, Kınıklı Campus, 20070, Denizli, Turkey
}

\author{
ARTICLE HISTORY \\ Received: 27 June 2019 \\ Revised: 18 August 2019 \\ Accepted: 25 September 2019 \\ KEYWORDS \\ Mathematics anxiety, \\ Mathematics teaching anxiety \\ Prospective teachers, \\ Reliability, \\ Validity, \\ Scale
}

\begin{abstract}
This study aimed to develop mathematics teaching anxiety scale for prospective primary school teachers. It was designed based on survey method and conducted with four sampling group consisting of 956 prospective primary school teachers at Education Faculties in Turkey. First sampling group was consisted of 404 prospective primary school teachers and 96 out of it were involved in the application of open-ended questions and 308 were involved in exploratory factor analysis. 305 prospective primary school teachers in the second sampling group participated in the confirmatory factor analysis, 108 prospective teachers in the third group were involved in criterion validity and 139 prospective teachers in the fourth one participated in the test-retest reliability analysis. As a result of the principal component analysis of the Mathematics Teaching Anxiety Scale (MTAS), it was found that the scale indicating single factor structure and consisting of 31 items (47.43\% of the total variance). After suggested modifications, the scale MTAS was constructed with 19 items. 12 items were removed from the scale and the confirmatory factor analysis (CFA) was carried out with 19 items. According to CFA results $(0 \leq \mathrm{X} 2 / \mathrm{df}=$ $1.483 \leq 2, \mathrm{RMSEA}=0.040, \mathrm{RMR}=0.050, \mathrm{AGFI}=0.908, \mathrm{TLI}=0.972, \mathrm{CFI}$ $=0.976, \mathrm{IFI}=0.976$, GFI $=0.928, \mathrm{NFI}=0.930$ and $\mathrm{RFI}=0.919)$, it was confirmed that the scale structure was consisting of 19 items and one dimension. The Cronbach's alpha coefficient of the final form of Mathematics Teaching Anxiety Scale was calculated as 0.93 .
\end{abstract}

\section{INTRODUCTION}

A global improvement in Information and Communication Technology (ICT) and being an interconnected world cause differences in not only individuals' social lives but also their school lives. The rapid change in the world enables individuals to share their knowledge effortlessly and this situation results in being aware of improvements and innovations around the world. Due to these changes, the content of education in terms of disciplines and teaching strategies and styles of them are also changing (Voogt \& Roblin, 2010; Trilling \& Fadel, 2009).

Students of new world need to gain a set of competencies that would help them better coping with the compulsive demands of 21 st century. In this sense, it could be said that mathematics is crucial for $21^{\text {st }}$ century skills in that it enables to think analytically, critically and creatively which then enable to gain problem solving and reasoning skills. This means mathematics helps thinking analytically, having better problem-solving skills and having better reasoning abilities.

CONTACT: Vesile ALKAN $₫$ vesile@pau.edu.tr @ Pamukkale University, Faculty of Education, Kınıklı Campus, 20070, Denizli, Turkey 
These skills are significant in providing individuals to find out the way of solving problems and looking for solutions in their lives. Therefore, learning and teaching mathematics in schools has become even more significant in today's world.

As emphasized by Tobias (1978) learning mathematics is intellectual but also emotional. Learning mathematics is related with how students can solve mathematical operations, how they can comprehend mathematical literacy and how they are competent in mathematics. However, it should be also noted that learning mathematics is also related with how students use their cognitive intelligences on how to succeed. On the one hand this suggests cognition and emotion are intertwisted in learning mathematics. On the other hand, even though mathematics and mathematical knowledge are used not only in schools but also regularly in everyday lives, students may avoid learning mathematics due to negative emotional reactions.

Many studies (Aiken, 1970; Alkan, 2009; 2010; 2011 \& 2013; Ashcraft, 1995; Baloğlu, 1999; Bessant, 1992; Bourne, 1995; Campbell \& Evans, 1997; Chipman, Krantz \& Silver, 1992; Dowker, Sarkar, \& Looi, 2016; Gierl \& Bisanz, 1995; Hembree, 1990; Izard, 1972; Kitchens, 1995; Ma \& Xu, 2004; Peker \& Ertekin, 2011; Posamentier \& Stepelman, 1986; Richardson, 1980; Skiba, 1990; Şahin, 2004; Tobias, 1978; Tobias, 1990; Vukovic, Kieffer, Bailey \& Harari, 2013; Wu, Willcutt, Escovar \& Menon; 2014; Zettle \& Houghton, 1998; Zettle \& Raines, 2000) indicated that some students at different grades of schools have negative attitudes towards mathematics which in turn cause feeling anxiety in mathematics. As suggested by given studies, it can be said that there is a lack in considering affective features of students in mathematics. In addition to this, it is suggested that students' anxiety in mathematics is attributable to such reasons like personality, parents, peers as well as teachers along with their teaching strategies and styles.

It can be accepted that teachers are one of the most powerful influences on students' learning of mathematics. Bandura (1993) emphasized that "teachers' beliefs in their personal efficacy to motivate and promote learning affect the types of learning environments they create and the level of academic progress their students achieve" (p. 117). From this point, it can be said that self-efficacy can be the predictor of teachers' effectiveness in mathematics (Hashmi \& Shaikh, 2011; Swackhammer, Koellner, Basile, \& Kimborough, 2009). Additionally, a wide body of studies (Alkan, 2009; 2011; Fiore, 1999; Geist, 2010; Sheilds, 2006; Sloan, 2010; Stuart, 2000) determined that teachers can cause, increase or reduce students' anxiety in mathematics at all levels of schooling on account of their attitudes and behaviours along with the teaching methods and the instructional strategies they use.

Swars, Daane \& Giesen (2006) stated that there was a negative relationship between selfefficacy for teaching and mathematics anxiety. This means teacher with high level self-efficacy can convey their confidence in mathematics to students (Mji \& Arigbabu, 2012) whereas those with low self-efficacy can cause students to feel negative attitudes towards mathematics. It was found in studies that teachers who are mathematics anxious fail in conveying important mathematical concepts and in allocating enough time for teaching these important concepts (Alkan, 2009; Dunkle, 2010; Fiore, 1999; Hembree, 1990 and Stuart, 2000). It can be also assumed that mathematics anxious teachers can transfer their negative attitudes in mathematics to their students.

Learning mathematics and teaching mathematics can be affected not only by the level of students' anxiety but also by the level of teachers' mathematics anxiety along with their teaching anxiety in mathematics (Alkan, 2009, 2011 and Baloğlu, 2001). The results of some studies indicated that there was a strong relation between teachers' mathematics anxiety and mathematics teaching anxiety (Bursal \& Paznokas, 2006; Gresham, 2008; Swars et al., 2006). Furthermore, it was found that teachers' negative feelings and attitudes in teaching mathematics can create anxiety and increase the level of anxiety of students in mathematics (Alkan, 2009, 
2011; Baloğlu, 1999; Beilock \& Willingham, 2014; Finlayson, 2014; Furner \& Berman, 2003; Sparks, 2011; Uusumaki \& Nason, 2004; Vinson, 2001).

Mathematics teaching anxiety can be define as teachers' feeling negative reaction to mathematics, feeling under pressure to teach mathematics and being frustrated with the lack of progress in mathematics. Teachers who feel anxiety in teaching mathematics might have fear of explaining concepts, formulae and operations in mathematics. However, it should be noted that mathematics is cumulative; there is a relation between prior knowledge, current and further knowledge in mathematics. This means the teacher needs to clarify each topic in mathematics in order not to cause students to fall behind. In addition to this, the teacher needs to help students to comprehend each concepts and operations in mathematics clearly.

Ölmez and Cohen (2018) emphasized that teachers are expected to provide supportive classroom setting in which lessening students' negative feelings towards mathematics. Furthermore, teachers are expected to enhance students' involvement in mathematics by helping to build connections with real-life situations and also building their self-confidence in mathematics. Although these expectations are specified, it should be considered that teachers having negative attitudes towards mathematics and teaching mathematics can fail in meeting these. Therefore, it is crucial to find out the level of mathematics teaching anxiety of teachers to deal with their anxieties in teaching mathematics.

As given in many studies above, there is an association between students' negative feelings in mathematics and teachers' anxiety and teaching anxiety in mathematics. It should be noted that feeling anxiety in mathematics can be started at primary school and raise at other levels of schooling and can transfer to the professional life. Like teachers, prospective teachers' teaching efficacy and self-confidence in mathematics can have an impact on their learning mathematics and then their teaching process (Hudson, Kloosterman\& Galindo, 2012). Levine (1993; 1996) claimed that prospective teachers have difficulties in teaching mathematics due to their teaching anxiety. Hence, mathematics anxious prospective teachers may avoid mathematics and mathematics related courses which in turn cause teaching in a way that unconsciously leading their students to feel anxiety in mathematics.

Prospective teachers especially for primary schools are significant resources for future mathematics lessons in schools and for improving future students' self-efficacy in mathematics. For this reason, it is needed to improve their teaching efficacy in mathematics in order to help these future teachers to be successful in their teaching in mathematics (Ryang, 2012). Gurin and et al, (2017) stated that there was a slight increase on studies conducted to find out the relation between teachers' mathematics anxiety and students' mathematic anxiety. Moreover, it is seen that there is a few studies focusing on prospective teachers' teaching anxiety in mathematics. These situations show that there is a need to investigate teachers' and prospective teachers' mathematics teaching anxiety in order to find out the ways of diminishing their and students' anxiety in mathematics. It is assumed that the results of studies focusing on mathematics teaching anxiety can contribute to the area of teaching mathematics. On the other hand, there is also need to find out the level of prospective teachers' mathematics teaching anxiety in order to help them to reduce or overcome this anxiety. Consequently, this study aimed to develop a scale for mathematics teaching anxiety based on prospective primary school teachers' perceptions.

\section{METHOD}

This study was designed in terms of quantitative approach to construct a scale for mathematics teaching anxiety for prospective teachers. To this view, a scale development steps were used. 


\subsection{Sampling}

The participants of this study consisted of 956 prospective primary school teachers at Education Faculties in Turkey. These participants were included in four different sampling groups. The first group of this study was consisted of 404 prospective primary school teachers and 96 prospective teachers from this group were used in the application of open-ended questions and 308 of them $(\bar{X}=21.87, \mathrm{Sd}=1.83$; female $=233$, male $=75)$ were used for exploratory factor analysis. A total of $305(\overline{\mathrm{X}}=21.95, \mathrm{Sd}=1.31$; Female $=234$, Male $=71)$ prospective primary school teachers in the second sampling group were used for confirmatory factor analysis, 108 prospective primary school teachers in the third group $(\bar{X}=21.80, \mathrm{Sd}=1.01$; Female $=91$, Male $=10$ ) were used for criterion validity studies. Lastly, 139 prospective primary school teachers in the fourth sampling group (female $=111$; male $=28$ ) were included in test-retest reliability studies.

\subsection{Assessment Measures}

During the development of the Turkish version of Mathematics Teaching Anxiety Scale (MTAS), the steps proposed by De Vellis (2014), Tavşancıl (2006) and Erkuş (2014) were followed. In order to develop the scale, first of all, the literature and assessment tools were reviewed and examined. After that, the form including open-ended questions was given to prospective primary school teachers and based on their answers 57 items were prepared for the scale within the conceptual frame. Then, the draft scale form was sent to the experts who worked on such topics as mathematics teaching, anxiety and mathematics anxiety. This supported the content-related validity of the scale. In line with the recommendations of these experts, 5 items were removed from the form and suggested corrections were done. After the scale's items were clarified according to the views, the original form of the scale consisting of 52 items was designed.

Items were rated on a 5-point Likert type ranging from 1 to 5 . The ranges of the scale were 1 (Strongly disagree), 2 (Slightly agree), 3 (Partially agree), 4 (Mostly agree), and 5 (Completely agree). Volunteer prospective primary school teachers were involved in data collection process. Before the data collection the participants were informed about the study and the data collection tool.

In order to perform confirmatory factor analysis, the Mathematics Teaching Efficacy Beliefs Instrument (MTEBI) was used. This instrument was used to measure prospective teachers' efficacy beliefs in teaching mathematics. The original scale was developed by Enochs, Smith \& Huinker (2000). Its first adaptation to Turkish was carried out by Çakıroğlu (2000), and the second one was by Haciömeroğlu \& Şahin - Taşkın (2010). The current adapted version of the scale was used in the present study. This instrument was consisted of 17 items and 7 out of these items were scored reversely.

\subsection{Data Analysis}

SPSS 22.00 package program and AMOS 18.00 program were used to analyse the data. The principal component analysis within the scope of exploratory factor analysis (EFA) was performed using the Kaiser Criteria (eigenvalue $>1$ ). After finding by the exploratory factor analysis that the scale was uni-dimensional, the Cronbach Alpha coefficient was calculated to determine the internal consistency of the scale. Confirmatory factor analysis was done with the help of AMOS 18.00 program (Byrne, 2009). For the criterion validity of the scale, Pearson product moment correlation coefficient was measured between the Mathematics Teaching Efficacy Belief Instrument (MTEBI) and the scale. In the analysis phase, whether the data had a univariate normal distribution in each study group was examined at first. It was determined that the data obtained from all study groups had a univariate normal distribution and the skewness and kurtosis values were between -1 and +1 (Muthén \& Kaplan, 1985). 


\section{RESULTS}

\subsection{Exploratory Factor Analysis}

While doing the Exploratory Factor Analysis (EFA), primarily the data gathered from the study group with whom MTAS consisting of 52 items applied was investigated. In this context, the chi-square value of the Bartlett Sphericity Test was found to be significant with 8973.88 ( $p$ $<0.000)$, and the Kaiser-Meyer-Olkin value (0.949) was found to be sufficient. In the light of these results, it was determined that the data obtained from the first study group was suitable for factor analysis (Albayrak, 2006; Şencan, 2005). In order to determine the factor structure of the MTAS, a single-factor structure consisting of 31 items was determined as a result of the principal components analysis carried out based on the criteria of screen-plot and eigenvalue> 1.0 and it was revealed that this structure explained $47.43 \%$ of the total variance (Kline, 1994).

The Cronbach Alpha coefficient was preferred in the calculation of the reliability coefficient of the MTAS, since it yielded consistent results in determining the reliability of the assessment tools with a single factor structure (Tan, 2009). In this respect, the lowest acceptable value for Chronbach Alpha coefficient was determined to be $\geq 0.70$. The reliability value of the MTAS was found to be 0.96, which is a high value (Hair, Anderson, Tatham \& Black, 1998; Nunnally \& Bernstein, 1994). The test-retest reliability coefficient of the MTAS was calculated to be 0.703 and this value was considered equal to the acceptable limit value. The factor loadings of the items on the MTAS, common variance and Cronbach Alpha coefficient for the single-factor structure of the scale is given in Table 1.

Table 1. Results of the Exploratory Factor Analysis of Mathematics Teaching Anxiety Scale $(N=308)$

\begin{tabular}{|c|c|c|c|}
\hline $\begin{array}{c}\text { Item } \\
\text { No }\end{array}$ & Item & Factor 1 & $\begin{array}{l}\text { Common } \\
\text { Variance }\end{array}$ \\
\hline M29 & $\begin{array}{l}\text { When a student does not understand mathematical operations, I get anxious about how } \\
\text { to explain them. }\end{array}$ & 0.770 & 0.613 \\
\hline
\end{tabular}

M27 A rise in the level differences among my students while teaching mathematics worries me.

Matematik dersini işlerken öğrencilerim arasında düzey farklılıklarının artmasından 0.747 endişelenirim.

M40 Until I gain experience in teaching, I feel fear about my lack of conveying mathematical concepts on time.

Deneyim kazanana kadar matematik kavramlarını zamanında kazandıramamaktan 0.737 korkarım.

M44 I feel worry about not being able to teach in mathematics according to my students' level.

Matematik dersini öğrencilerimin düzeylerine göre anlatamayacağım endişesi yaşarım.

M23 The thought that I cannot concretize the abstract concepts in mathematics frightens me. 0.730 Matematik dersinde soyut kavramları somutlaştıramama düşüncesi beni korkutur.

M35 I feel anxious while considering students' individual differences in teaching mathematics.

Matematik ögretirken bireysel farklılıkları göz önünde bulundurma zorunluluğu beni ${ }^{0.729}$ endişelendirir.

M43 I feel worry that I do not know how to teach mathematical concepts to students. Matematik kavramlarını kazandırırken nasıl öğreteceğimi bilmediğim için tedirgin 0.726 olurum.

M46 I feel anxious that I may fail in bringing my students having different readiness levels 0.724 to the same level in mathematics.

Matematik dersinde hazırbulunuşluk düzeyi farklı olan öğrencilerimi aynı düzeye getiremeyeceğim endişesi yaşarım.

M26 I feel anxious about not relating the content of mathematics with students' daily lives. Matematik dersinde işlenecek konuyu günlük yaşamla ilişkilendiremeyeceğim endişesi 0.722 yaşarım. 
Table 1. Continues

\begin{tabular}{llc}
\hline $\begin{array}{l}\text { Item } \\
\text { No }\end{array}$ & Item & Factor 1 Common \\
Variance
\end{tabular} mathematics.
Matematik dersinde kendimi yeterli hissetmediğim konuları öğrencilerime nasıl kazandıracă̆ım endişesi yaşarım.

M25 I'm worried about not using the appropriate method and technique in mathematics. $\quad 0.697$ Matematik dersine uygun yöntem ve tekniği kullanamama endişesi yaşarım.

M41 I'm worried about not enabling my students' to engage in mathematics actively. 0.696 Öğrencilerimin matematik dersine aktif katılımını să̆layamama endişesi yaşarım.

M22 The thought that the student cannot comprehend when I turn a concept into a 0.696 mathematical sentence (e.g. $2+3$ ) makes me anxious.

Bir kavramı matematiksel cümleye (ör: 2+3) dönüştürdüğümde öğrencinin anlayamayacă̆ düşüncesi beni tedirgin eder.

M34 I get anxious about designing activities that are appropriate for my students' level in mathematics.

Matematik dersinde ögrencilerimin düzeyine uygun etkinlik hazırlama endişesi yaşarım.

M49 The thought that the level differences of the students in mathematics may reduce the interest of attending the lesson disturbs me.

Matematik dersinde ögrencilerin düzey farklılıklarının derse olan ilgiyi azaltacağ düşüncesi beni rahatsız eder.

M39 I feel uneasy with the thought that I cannot enable my students to like mathematics. Matematiği sevdiremeyeceğim düşüncesi beni huzursuz eder.

M18 I am afraid that the level differences of the students in mathematics may affect my teaching pace.

Matematik dersinde öğrencilerin düzey farklılıklarının ders işleme hızımı etkilemesinden korkarım.

M21 I am afraid that students with fewer interests in mathematics may reduce the interest of other students.

Matematik dersine ilgisi az olan öğrencilerin diğer ögrencilerin ilgisini azaltmasından korkarım.

M37 I am afraid that families will criticize me if I cannot catch up with the mathematics curriculum.

Matematik programını yetiştiremezsem ailelerin beni eleştirmesinden huzursuz olurum.

M33 I am afraid that school administrators will criticize me if I cannot catch up with the mathematics curriculum.

Matematik programını yetiştiremezsem okul yöneticilerinin beni eleştirmesinden korkarım.

M19 The fact that my students have different readiness levels in mathematics frightens me in the early years of my professional life.

Meslek yaşantımın ilk yıllarında öğrencilerimin matematik dersindeki hazırbulunuşluk düzeylerinin farkl olması beni korkutur.

M28 I am anxious since I believe that I do not have sufficient knowledge about teaching mathematics.

Matematik ögretimine yönelik yeterli bilgiye sahip olmadı̆̆ımı düşündüğümden endişelenirim.

M48 I feel fear of being humiliated by the students if I cannot solve problems in mathematics. Matematik dersinde problemleri çözemezsem öğrencilerin gözünde küçük düşmekten korkarım.

M24 It makes me uncomfortable to know that the next lesson I will teach is mathematics. 
Table 1. Continues

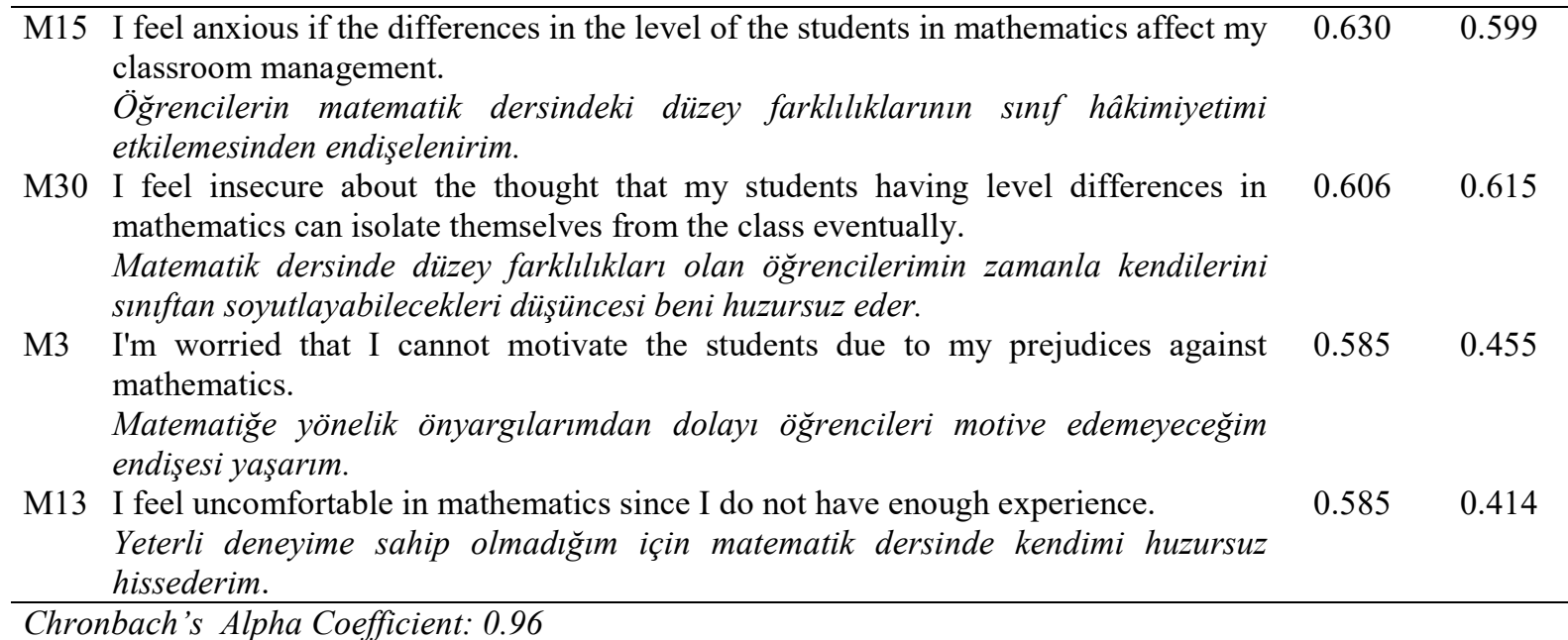

\subsection{Confirmatory Factor Analysis}

AMOS 18.00 program was used in order to perform the confirmatory factor analysis (CFA) of the MTAS and maximum likelihood method was opted for the estimation of model parameters (Tezbaşaran, 1997). The structure consisting of 31 items and one dimension as a result of exploratory factor analysis was tested via confirmatory factor analysis. The result of the analysis indicated that some of the items exhibited a high correlation with each other.

In this respect, the items exhibiting correlations were removed from the scale. Yet, after suggested modifications, the scale MTAS was constructed with 19 items and one dimension. The confirmatory factor analysis values of the MTAS and the suggested are illustrated in Figure 1.

It is stated that there are three types of fit that are practical for all fit measures and can be represented as absolute, incremental and restricted fit in the CFA (Schumacker and Lomax, 2010). In this study, $X^{2}$, RMSEA, GFI and RMR were used to evaluate the absolute fit. AGFI, NFI, TLI, CFI, RFI and IFI were used as incremental fit measures. The fit values for CFA are shown in Table 2.

Table 2. Goodness of Fit Indices in the Confirmatory Factor Analysis

\begin{tabular}{lccccccccccc}
\hline$X^{2}$ & $X^{2} / d f$ & $p$-value & RMSEA & GFI & RMR & AGFI & NFI & TLI & CFI & RFI & IFI \\
\hline $220.963^{*}$ & 1.483 & 0.000 & 0.040 & 0.928 & 0.050 & 0.908 & 0.930 & 0.972 & 0.976 & 0.919 & 0.976 \\
\hline
\end{tabular}

${ }^{*} p<0.01$

When Table 2 is examined, it is seen that $\mathrm{X}^{2}$ value $\left(\mathrm{X}^{2}=220.963\right.$; $\left.\mathrm{df}=126, p<0.01\right)$ is significant (Timm, 2002). However, this statistic is considered to be a weak absolute fit (Timm, 2002). When the relevant literature is reviewed, it is observed that $X^{2}$ value is significant in large samples (Byrne, 1989). For this reason, $\mathrm{X}^{2} / \mathrm{df}$, which is another proposed statistic, was calculated and it was found that this statistic $\left(0 \leq X^{2} / d f=1.483 \leq 2\right)$ showed good fit (Kline, 2011; Sümer, 2000). When the other fit indices were examined, it was observed that RMSEA (0.040), RMR (0.050), AGFI (0.908), TLI (0.972), CFI (0.976) and IFI (0.976) showed a good fit. The indices with acceptable fit values included GFI (0.928), NFI (0.930) and RFI (0.919) (Hair, Black, Babin \& Anderson, 2014; Browne \& Cudeck, 1993; Baumgartner \& Homburg, 1996; Bentler, 1980; Bentler \& Bonett, 1980; Marsh, Hau, Artelt, Baumert \& Peschar, 2006; Schermelleh-Engel \& Moosbrugger, 2003; Kline,1991). When these values are examined, it can be stated that the MTAS has a good fit. Table 3 shows the 19-item MTAS, standardized factor loadings and standard error values of this scale. 


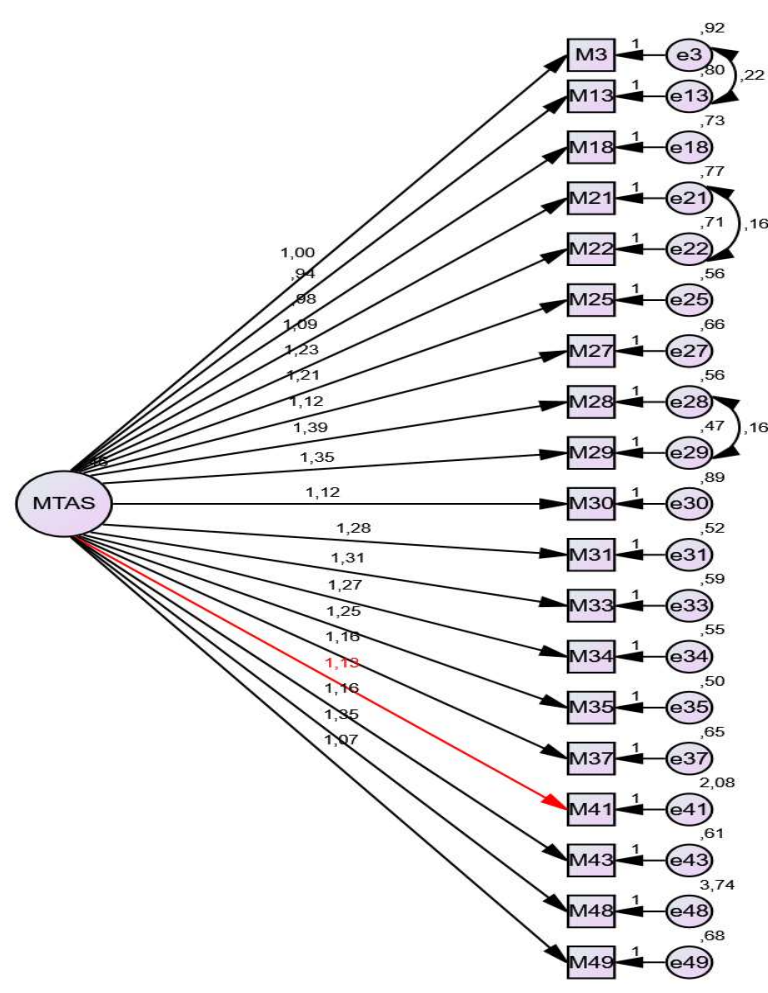

Figure 1. Results of the Confirmatory Factor Analysis of MTAS

Table 3. Confirmatory Factor Analysis Item Statistics

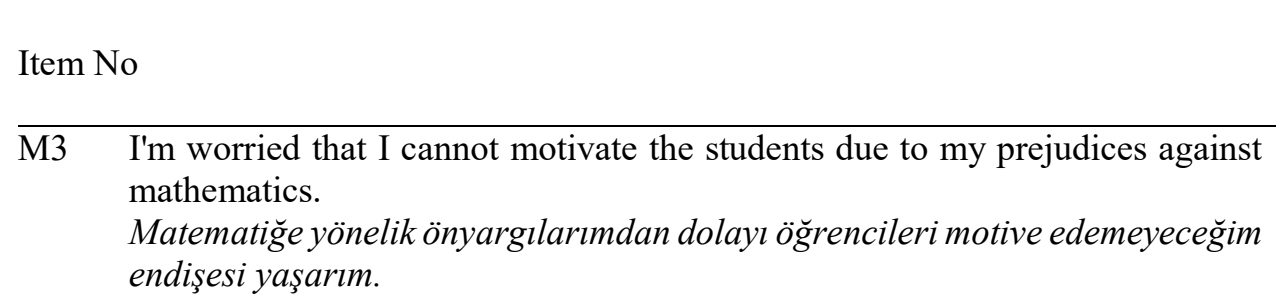

M13 I feel uncomfortable in mathematics since I do not have enough experience.

Yeterli deneyime sahip olmadığım için matematik dersinde kendimi huzursuz hissederim.

M18 I am afraid that the level differences of the students in mathematics may affect my teaching pace.

Matematik dersinde öğrencilerin düzey farklllıklarının ders işleme hızımı etkilemesinden korkarım.

M21 I am afraid that students with fewer interests in mathematics may reduce the Standardized

Factor S.E.

Loadings interest of other students.

Matematik dersine ilgisi az olan öğrencilerin diğer öğrencilerin ilgisini azaltmasindan korkarim.

M22 The thought that the student cannot comprehend when I turn a concept into a mathematical sentence (e.g. $2+3$ ) makes me anxious.

Bir kavramı matematiksel cümleye (ör: 2+3) dönüştürdüğümde öğrencinin anlayamayacağı düşüncesi beni tedirgin eder.

M25 I'm worried about not using the appropriate method and technique in mathematics.

Matematik dersine uygun yöntem ve tekniği kullanamama endişesi yaşarım.

M27 A rise in the level differences among my students while teaching mathematics worries me.

Matematik dersini işlerken öğrencilerim arasında düzey farklıllklarının artmasindan endişelenirim. 
Table 3. Continues

\begin{tabular}{|c|c|c|c|}
\hline $\begin{array}{l}\text { Item } \\
\text { No }\end{array}$ & & $\begin{array}{l}\text { Standardized } \\
\text { Factor } \\
\text { Loadings }\end{array}$ & S.E. \\
\hline 28 & $\begin{array}{l}\text { I am anxious since I believe that I do not have sufficient knowledge about } \\
\text { teaching mathematics. } \\
\text { Matematik öğretimine yönelik yeterli bilgiye sahip olmadı̆̆ımı } \\
\text { düsündüğ̈̈mden endiselenirim. }\end{array}$ & 0.783 & 0.134 \\
\hline M29 & $\begin{array}{l}\text { When a student does not understand mathematical operations, I get anxious } \\
\text { about how to explain them. } \\
\text { Matematiksel işlemleri ögrenci anlamadığında nasıl açıklayacağım endişesi } \\
\text { yaşarım. }\end{array}$ & 0.800 & 0.129 \\
\hline M30 & $\begin{array}{l}\text { I feel insecure about the thought that my students having level differences in } \\
\text { mathematics can isolate themselves from the class eventually. } \\
\text { Matematik dersinde düzey farklılıkları olan ögrencilerimin zamanla } \\
\text { kendilerini sinıftan soyutlayabilecekleri düşüncesi beni huzursuz eder. }\end{array}$ & 0.628 & 0.125 \\
\hline M31 & $\begin{array}{l}\text { I feel anxious that I cannot finish the outcomes of the mathematics curriculum } \\
\text { on time. } \\
\text { Matematik programındaki kazanımları zamanında bitiremeyeceğim endişesi } \\
\text { yaşarım. }\end{array}$ & 0.770 & 0.124 \\
\hline$[33$ & $\begin{array}{l}\text { I am afraid that school administrators will criticize me if I cannot catch up with } \\
\text { the mathematics curriculum. } \\
\text { Matematik programını yetiştiremezsem okul yöneticilerinin beni } \\
\text { eleştirmesinden korkarım }\end{array}$ & 0.757 & 0.129 \\
\hline M34 & $\begin{array}{l}\text { I get anxious about designing activities that are appropriate for my students' } \\
\text { level in mathematics. } \\
\text { Matematik dersinde ögrencilerimin düzeyine uygun etkinlik hazırlama } \\
\text { endişesi yaşarım. }\end{array}$ & 0.757 & 0.125 \\
\hline M35 & $\begin{array}{l}\text { I feel anxious while considering students' individual differences in teaching } \\
\text { mathematics. } \\
\text { Matematik öğretirken bireysel farklılıkları göz önünde bulundurma } \\
\text { zorunluluğu beni endişelendirir. }\end{array}$ & 0.767 & 0.122 \\
\hline 137 & $\begin{array}{l}\text { I am afraid that families will criticize me if I cannot catch up with the } \\
\text { mathematics curriculum. } \\
\text { Matematik programın yetiştiremezsem ailelerin beni eleştirmesinden } \\
\text { huzursuz olurum. }\end{array}$ & 0.701 & 0.120 \\
\hline M41 & $\begin{array}{l}\text { I'm worried about not enabling my students' to engage in mathematics actively. } \\
\ddot{O} \breve{g r e n c i l e r i m i n ~ m a t e m a t i k ~ d e r s i n e ~ a k t i f ~ k a t ı l ı m ı n ı ~ s a g ̆ l a y a m a m a ~ e n d i s ̧ e s i ~} \\
\text { yaşarım. }\end{array}$ & 0.469 & 0.157 \\
\hline M43 & $\begin{array}{l}\text { I feel worry that I do not know how to teach mathematical concepts to students. } \\
\text { Matematik kavramlarını kazandırırken nasıl ögreteceğimi bilmediğim için } \\
\text { tedirgin olurum. }\end{array}$ & 0.709 & 0.119 \\
\hline M48 & $\begin{array}{l}\text { I feel fear of being humiliated by the students if I cannot solve problems in } \\
\text { mathematics. } \\
\text { Matematik dersinde problemleri çözemezsem ögrrencilerin gözünde küçük } \\
\text { düşmekten korkarım. }\end{array}$ & 0.427 & 0.203 \\
\hline M49 & $\begin{array}{l}\text { The thought that the level differences of the students in mathematics may } \\
\text { reduce the interest of attending the lesson disturbs me. } \\
\text { Matematik dersinde ögrencilerin düzey farklıliklarının derse olan ilgiyi } \\
\text { azaltacağl düşüncesi beni rahatsı eder. }\end{array}$ & 0.660 & 0.115 \\
\hline
\end{tabular}

Chronbach's Alpha: 0.93

\subsection{Criterion Validity}

Within the scope of the criterion validity studies of the MTAS, prospective primary school teachers in the third group were asked to fill in the Mathematics Teaching Efficacy Belief Instrument and the Mathematics Teaching Anxiety Scale in order to measure the Pearson 
product moment correlation coefficient. It was found that the correlation coefficient showed a moderately negative $(\mathrm{r}=-0.43)$ and significant $(\mathrm{p}<0.01, \mathrm{n}=108)$ relationship (Büyüköztürk, 2012; Field, 2009). In the light of these results, it can be said that the MTAS has concurrent validity.

\section{CONCLUSION}

This study aimed to develop and examine a scale for measuring mathematics teaching anxiety (MTAS) for prospective primary school teachers. To this aim, 956 prospective primary school teachers were involved in this study in order to construct and to prove the validity and reliability of the scale. At the beginning of the study, a scale was designed with 57 items and sent to experts for content-related validity. After their judgements, the scale was structured with 52 items.

Before the factor analysis process, it was found that the chi-square value of the Bartlett Sphericity Test was significant with $8973.88(p<0.000)$, and the Kaiser-Meyer-Olkin value was sufficient (0.949). According to the results of the exploratory factor analysis, it was found that the scale indicates single factor structure and consisting of 31 items. The reliability value of the scale with 31 items was found to be 0.96 , which is a high value. In addition to this, the testretest reliability coefficient was calculated to be 0,703 was considered equal to the acceptable limit value.

Confirmatory factor analysis was also used to determine the correlations among items. In this analysis, it was found that some items were exhibiting high correlations; therefore, those items were removed from the scale. As a result, the structure of the scale was constructed with 19 items. In terms of CFA results $(0 \leq \mathrm{X} 2 / \mathrm{df}=1.483 \leq 2, \mathrm{RMSEA}=0.040, \mathrm{RMR}=0.050$, AGFI $=0.908, \mathrm{TLI}=0.972, \mathrm{CFI}=0.976, \mathrm{IFI}=0.976, \mathrm{GFI}=0.928, \mathrm{NFI}=0.930$ and $\mathrm{RFI}=0.919)$, it was confirmed that the scale structure was consisting of 19 items and one dimension. Thereafter, the criterion validity was measured and found that the scale has concurrent validity. In conclusion, the final form of Mathematics Teaching Anxiety Scale (MTAS) for prospective primary school teachers was consisting of 19 items and the Cronbach's alpha coefficient of this scale was 0.93 . It is believed that this MTAS can contribute to the area by helping to measure the level of prospective teachers' mathematics teaching anxiety. Furthermore, this scale could be one of the measurements in the area which can help other research to construct new scales and to focus on mathematics teaching anxiety in various ways.

\section{ORCID}

\section{Vesile ALKAN (iD https://orcid.org/0000-0002-8630-3357}

\section{REFERENCES}

Aiken, L. R. (1970). Attitudes toward mathematics. Review of Educational Research, 40 (4), 551-596.

Albayrak, A. S. (2006). Uygulamalı Çok Değişkenli İstatistik Teknikleri. Ankara: Asil Yayın Dağıtım.

Alkan, V. (2009). The Relationship between teaching strategies and styles and pupils' anxiety in mathematics at primary schools in Turkey. Unpublished PhD Thesis. The University of Nottingham.

Alkan, V. (2010). Matematikten nefret ediyorum! [I hate Mathematics!]. Pamukkale Üniversitesi Eğitim Fakültesi Dergisi [Pamukkale University Journal of Education], 28 (II), 189-199.

Alkan, V. (2011). Etkili matematik öğretiminin gerçekleştirilmesindeki engellerden biri: kayg1 ve nedenleri [One of the barriers to providing effective mathematics teaching: anxiety 
and its causes]. Pamukkale Üniversitesi Eğitim Fakültesi Dergisi [Pamukkale University Journal of Education], 29(I), 89-107.

Alkan, V. (2013). Reducing mathematics anxiety: The ways implemented by teachers at primary schools in Turkey. International J. Soc. Sci. \& Education, 3 (3), 795-807.

Ashcraft, M. H. (1995). Cognitive psychology and simple arithmetic: A review and summary of new directions. Mathematical Cognition, 1, 3-34.

Ashcraft, M. H. (2002). Math anxiety: Personal, educational, and cognitive consequences. Current Directions in Psychological Science, 11(5), 181-185.

Baumgartner, H., \& Homburg, C. (1996). Applications of structural equation modelling in marketing and consumer research: A review. International Journal of Research in Marketing, 13(2), 139-161.

Baloğlu, M. (1999). A comparison of mathematics anxiety and statistics anxiety in relation to general anxiety. Eric Document Number (ED 436 703).

Baloglu, M. (2001). Matematik Korkusunu Yenmek. Kuram ve Uygulamada Eğitim Bilimleri Dergisi, 1 (1), 59-76.

Bandura, A. (1993). Perceived self-efficacy in cognitive development and functioning. Educational Psychologist. 28, 117-148.

Beilock, S. L., Gunderson, E. A., Ramirez, G., \& Levine, S. C. (2010). Female teachers' math anxiety affects girls' math achievement. Proceedings of the National Academy of Sciences, 107 (5), 1860-1863.

Beilock, S. L. \& Willingham, D. T. (2014). Ask the cognitive scientist. Math anxiety: Can teachers help students reduce it? American Educator, 38(2), 28-43

Bentler, P. M. (1980). Multivariate analysis with latent variables: Causal modelling. Annual Review of Psychology, 31, 419-456.

Bentler, P. M. \& Bonett, D. G. (1980). Significance tests and goodness of fit in the analysis of covariance structures. Psychological Bulletin, 88, 588-606.

Bessant, K. C. (1992). Instructional design and the development of statistical literacy. Teaching Sociology, 20, 143-149.

Bowd, A. \& Brady, P. (2003). Gender differences in mathematics anxiety among preservice teachers and perceptions of their elementary and secondary school experience with mathematics. The Alberta Journal of Educational Research, XLIX (1), 24-36.

Browne, M. W., \& Cudeck, R. (1993). Alternative ways of assessing model fit. In K. A. Bollen and J. S. Long (Eds.), Testing structural equation models (pp. 136-162). Newbury Park, CA: Sage.

Bursal M., \& Paznokas, L. (2006). Mathematics anxiety and pre-service elementary teachers' confidence to teach mathematics and science. School Science and Mathematics, 106 (4) 173-179.

Bourne, E. (1995). The Anxiety and Phobia Workbook (2 ${ }^{\text {nd }}$ Ed.). Akland, CA: New Harbiner Publications.

Byrne, B. M. (1989). A Primer of LISREL: Basic Applications and Programming for Confirmatory Factor Analytic Models. New York: Springer-Verlag.

Büyüköztürk, Ş. (2012). Sosyal Bilimler İçin Veri Analizi El Kitabı, İstatistik, Araştırma Deseni SPSS Uygulamalarl ve Yorumu. Ankara: PegemA Yayınc1l1k.

Byrne, B. M. (2009). Structural equation modelling with Amos: Basic concepts, applications and programming ( $2^{\text {nd }} E d$.). Mahwah, $\mathrm{NJ}$ : Erlbaum.

Campbell, K. \& Evans, C. (1997). Gender issues in the classroom: A comparison of mathematics anxiety. Education, $117(3), 332-339$.

Chipman, S.F., Krantz, D. H. \& Silver R. (1992). Mathematics anxiety and science careers among able college women. Psychological Science, 3, 292-295. 
Çakıroğlu, E., 2000. Preservice Elementary Teachers' Sense of Efficacy in Reform Oriented Mathematics. Yayınlanmamış Doktora Tezi, Indiana University. Retrieved from ProQuest Dissertations \& Theses Global. (Order No. 9980980)

Deniz, L. ve Üldaş, İ. (2008). Öğretmen ve öğretmen adaylarina yönelik matematik kayg1 ölçeği'nin geçerlik, güvenirlik çalışması. [Validity and reliability study of the mathematics anxiety scale involving teachers and prospective teachers]. Eurasian Journal of Educational Research, 30, 49-62.

DeVellis, R. F. (2014). Ölçek Geliştirme Kuram ve Uygulamalar (3. Baskı). (T. Totan, Çev. Ed.). Ankara: Nobel Akademi Yayınları.

Dowker, A., Sarkar, A. \& Looi, C. Y. (2016). Mathematics anxiety: What have we learned in 60 years? Front. Psychol. 7, 508. DOI: 10.3389/fpsyg.2016.00508

Dunkle, S. M. (2010). Remediation of math anxiety in preservice elementary school teachers (Doctoral dissertation). Retrieved from ProQuest Dissertations \& Theses Global. (Order No. 3411597)

Enochs, L., Smith, P. L., \& Huinker, D. (2000). Establishing factorial validity of the mathematics teaching efficacy beliefs instrument. School Science and Mathematics, 100(4), 194-202.

Erkuş, A. (2014). Psikolojide Ölçme ve Ölçek Geliştirme - I Temel Kavramlar ve İşlemler (2.Basım). Ankara: Pegem Akademi.

Field, A. (2009). Discovering Statistics Using SPSS ( $3^{\text {rd }}$ Ed.). London: Sage Publications Ltd.

Finlayson, M. (2014). Addressing math anxiety in the classroom. Improving Schools, 17(1), 99-115, DOI: $10.1177 / 1365480214521457$

Fiore, G. 1999. Math-abused students: Are we prepared to teach them? The Mathematics Teacher, 92(5): 403-409.

Furner, J.M., \& Berman, B.T. (2003). Math Anxiety: Overcoming a major obstacle to the improvement of student math performance. Childhood Education, 79(3), 170-175.

Gardner, L. \& Leak, G. (1994). Characteristics and correlates of teaching anxiety among college psychology teachers. Teaching of Psychology, 21(1), 28-32.

Geist, E. (2010). The anti-anxiety curriculum: Combating math anxiety in the classroom. Journal of Instructional Psychology, 37 (1), 24-31.

Gierl, M. J. \& Bisanz, J. (1995). Anxieties and attitudes related to math in grades 3 and 6. Journal of Experimental Education, 63 (2), 139-158.

Goetz, T., Bieg, M., Lüdtke, O., Pekrun, R., \& Hall, N. C. (2013). Do girls really experience more anxiety in mathematics? Psychological Science, 24 (10), 2079-2087.

Gresham, G. (2008). Mathematics anxiety and mathematics teacher efficacy in elementary preservice teachers. Teaching Education, 19 (3), 171-184.

Gurin, A., Jeanneret, G., Pearson, M., Pulley, M., Salinas, A. \& Castillo-Garsow, C. (2017). The Dynamics of math anxiety as it is transferred through peer and teacher interactions (Technical Report MTBI-14-05M). Retrieved from Arizona State University Mathematical and Theoretical Biology Institute (MTBI) website: https://mtbi.asu.edu/sites/default/files/manuscript 0.pdf

Hacıömeroğlu, G. \& Şahin-Taşkın, Ç. (2010). Sınıf Öğretmeni adaylarının matematik öğretimi yeterlik inançları. [Elementary preservice teachers' mathematics teaching efficacy belief]. Uludă̆ Üniversitesi Eğitim Fakültesi Dergisi [Uludă̆ University Educaton Faculty Journal], 23(2), 539-555.

Hackett, G., \& Betz, N. E. (1989). An exploration of the mathematics self-efficacy/ mathematics performance correspondence. Journal for Research in Mathematics Education, 20 (3), 261-273. 
Hadfield, O. D. \& McNeil, K. (1994). The relationship between Myers-Briggs personality type and mathematics anxiety among preservice elementary teachers. Journal of Instructional Psychology, 21(4), 375-384.

Hair Jr., J. F., Anderson, R. E., Tatham, R. L., \& Black, W. C. (1998). Multivariate Data Analysis $\left(5^{\text {th }}\right.$ Ed.). Upper Saddle River, NJ: Prentice Hall.

Hair, Jr. J. F., Black, W. C., Babin, B. J. \& Anderson, R. E. (2014). Multivariate Data Analysis ( $7^{\text {th }}$ Ed.). USA: Pearson Education Limited

Hashmi, M. \& Shaikh, F. (2011). Comparative analysis of the effect of teacher education on motivation, commitment, and self-efficacy. New Horizons, 10(2), 54-58.

Hembree, R. (1990). The nature, effects and relief of mathematics anxiety. Journal of Research in Mathematics Education, 21, 33-46.

Hudson, R., Kloosterman, P. \& Galindo, E. (2012). Assessing preservice teachers' beliefs about the teaching and learning of mathematics and science. School Science and Mathematics, 112(7), 433-442.

Izard, C. E. (1972). Patterns of Emotions: A New Analysis of Anxiety and Depression. New York: Academic Press.

Kesici, S., \& Erdoğan, A. (2009). Predicting college students' mathematics anxiety by motivational beliefs and self-regulated learning strategies. College Student Journal, 43 (2), 631-642.

Kitchens, A. (1995). Defeating Math Anxiety. Chicago: Irwin Career Education Division.

Kline, R. B. (1991). Latent variable path analysis in clinical research: a beginner's tour guide. Journal of Clinical Psychology, 47, 471-484.

Kline P. (1994). An Easy Guide to Factor Analysis. London: Routledge.

Kline, R. B. (2011). Principles and Practice of Structural Equation Modelling. New York: The Guilford Press.

Levine, G. (1993). Prior mathematics history, anticipated mathematics teaching style, and anxiety for teaching mathematics among pre-service elementary school teachers. Paper presented at the Annual Meeting of the International Group for Psychology of Mathematics Education, North American Chapter. (ERIC Document Reproduction Service No. ED373972).

Levine, G. (1996). Variability in anxiety for teaching mathematics among pre-service elementary school teachers enrolled in a mathematics course. Paper presented at the Annual Meeting of the American Educational Research Assocation in New York. (ERIC Document Reproduction Service No. ED398067).

Ma, X. \& Xu, J. (2004). The causal ordering of mathematics anxiety and mathematics achievement: a longitudinal panel analysis. Journal of Adolescence, 27(2), 165-179.

Marsh, H.W., Hau, K.T., Artelt, C., Baumert, J., \& Peschar, J.L. (2006). OECD's brief selfreport measure of educational psychology's most useful affective constructs: Crosscultural, psychometric comparisons across 25 countries. International Journal of Testing, 6(4), 311-360.

Mji, A. \& Arigbabu, A. A. (2012). Relationships between and among pre-service mathematics teachers' conceptions, efficacy beliefs and anxiety. International Journal of Education of Science, 4(3), 261-270.

Muthe'n B. \& Kaplan, D. A. (1985). Comparison of methodologies for the factor analysis of non-normal Likert variables. British Journal of Mathematical and Statistical Psychology, $38,171-189$.

Nunnally, J.C. \& Bernstein, I. H. (1994). Psychometric Theory. NewYork: McGraw-Hill.

Olmez, I., \& Cohen, A. (2018). A Mixture Partial Credit Analysis of Math Anxiety. International Journal of Assessment Tools in Education, 5(4), 611-630. Retrieved from https://ijate.net/index.php/ijate/article/view/565 
Peker, M. \& Ertekin, E. (2011). The relationship between mathematics teaching anxiety and mathematics anxiety. The New Educational Review, 23 (1), 213-226.

Posamentier, A. S. \& Stepelman, J. (1986). Teaching secondary school mathematics. Ohio: Charles E. Merrill Publishing Company.

Richardson, M. F. (1980). An Assessment of Mathematics Anxiety Levels among Adult Basic and Adult Secondary Students (Unpublished Doctoral Thesis). The University of Georgia, Athens. Retrieved from ProQuest Dissertations \& Theses Global.

Ryang, D. (2012). Exploratory analysis of Korean elementary pre-service teachers' mathematics teaching efficacy beliefs. International Electronic Journal of Mathematics Education, 7(2), 45-61.

Schermelleh-Engel, K., Moosbrugger, H. \& Müller, H. (2003). Evaluating the fit of structural equation models: tests of significance and descriptive goodness-of-fit measures. Methods of Psychological Research Online, 8(2), 23-74.

Schumacker, R. E. \& Lomax, R. G. (2010). A beginner's guide to Structural Equation Modeling (3rd ed.). NJ: Lawrence Erlbaum Associates.

Skiba, A. (1990). Reviewing an old subject: Math anxiety. Mathematics Teacher, 83(3), 188189.

Sloan, T. R. (2010). A Quantitative and qualitative study of math anxiety among pre-service teachers, The Educational Forum, 74(3), 242-256.

Sparks, S. D. (2011). Researchers Probe Causes of Math Anxiety. Education Week, 30(31). Retrieved from http://www.edweek.org

Stuart, V. (2000). Math curse or math anxiety? Teaching Children Mathematics, 6, 30-340.

Sümer, N. (2000). Yapısal eşitlik modelleri: temel kavramlar ve örnek uygulamalar. [Structural equation modelling: Basic concepts and best practices] Türk Psikoloji Yazıları [Turkish Psychology Writings]. 3(6), 49-74.

Swackhammer, L., Koellner, K., Basile, C. \& Kimborough, D. (2009). Increasing the selfefficacy of inservice teachers through content knowledge. Teacher Education Quarterly, 36(2), 63-78.

Swars, S., Daane, C. \& Giesen, J. (2006). Mathematics anxiety and mathematics teachers' efficacy: What is the relationship in elementary pre-service teachers? School Science and Mathematics, 106 (7), 306-315.

Şencan, H. (2005). Sosyal ve Davranışsal Ölçümlerde Güvenlik ve Geçerlik. Ankara: Seçkin Yayınlar1.

Tan, Ş. (2009). KR-20 ve Cronbach Alfa Katsayılarının Yanlış Kullanımları [Misuses of KR20 and Cronbach's Alpha Reliability Coefficients] . Eğitim ve Bilim [Education and Science], 34 (152), 101-112.

Tavşancıl, E. (2006). Tutumların Ölçülmesi ve SPPS ile Veri Analizi (3.Basım).Ankara: Nobel Akademik Yayınc1lık.

Tezbaşaran, A. A. (1997). Likert Tipi Ölçek Geliştirme Kılavuzu (2.Basım).Ankara: Türk Psikologlar Derneği Yayınları.

Timm, N. H. (2002). Applied Multivariate Analysis. New York, NY: Springer.

Tobias, S. (1978). Overcoming Math Anxiety. Newyork: Norton.

Tobias, S. (1990). Math Anxiety: An Update. NACADA Journal, 10(1), 47-50.

Trilling, B. \& Fadel, C. (2009). 21st Century Skills: Learning for Life in Our Times. San Francisco, CA: John Wiley \& Sons.

Uusimaki, L. \& Nason, R. (2004). Causes underlying pre-service teachers' negative beliefs and anxieties about mathematics. Proceedings of the 28th Conference of the International Group for the Psychology of Mathematics Education, 4, 369-376. 
Vinson, B. (2001). A comparison of pre-service teachers' mathematics anxiety before and after a methods class emphasizing manipulatives. Early Childhood Education Journal, 29 (2), 89-94.

Voogt, J. \& Roblin, N. P. (2010). $21^{\text {st }}$ Century Skills. Enschede: University of Twente.

Vukovic, R. K., Kieffer, M. J., Bailey, S. P. \& Harari, R. R. (2013). Mathematics anxiety in young children: Concurrent and longitudinal associations with mathematical performance. Contemporary Educational Psychology, 38(1), 1 - 10. http://dx.doi.org/10. 1016/j.cedpsych.2012.09.001

Wu, S. S., Willcutt, E. G., Escovar, E. \& Menon, V. (2014). Mathematics achievement and anxiety and their relation to internalizing and externalizing behaviors. Journal of Learning Disabilities, 47(6), 503-514.

Zettle, R. D. \& Houghton, L. L. (1998). The relationship between mathematics anxiety and social desirability as a function of gender. College Student Journal, 32, 81-86.

Zettle, R. \& Raines, S. (2000). The relationship of trait and text anxiety with mathematics anxiety. College Student Journal, 34 (2), 246. 


\section{APPENDIX}

\section{Mathematics Teaching Anxiety Scale (MTAS-Turkish version) for Prospective Primary SchoolTeachers}

1 I'm worried that I cannot motivate the students due to my prejudices against mathematics. Matematiğe yönelik önyargılarımdan dolayı öğrencileri motive edemeyeceğim endişesi yaşarım.

2 I feel uncomfortable in mathematics since I do not have enough experience. Yeterli deneyime sahip olmadı̆̆ım için matematik dersinde kendimi huzursuz hissederim.

3 I am afraid that the level differences of the students in mathematics may affect my teaching pace. Matematik dersinde ögrencilerin düzey farklılıklarının ders işleme hızımı etkilemesinden korkarım.

$4 \quad$ I am afraid that students with fewer interests in mathematics may reduce the interest of other students. Matematik dersine ilgisi az olan öğrencilerin diğer öğrencilerin ilgisini azaltmasından korkarım.

$5 \quad$ The thought that the student cannot comprehend when I turn a concept into a mathematical sentence (e.g. $2+3$ ) makes me anxious.

Bir kavramı matematiksel cümleye (ör: 2+3) dönüştürdüğ̈̈mde ögrrencinin anlayamayacă̆ düşüncesi beni tedirgin eder.

$6 \quad$ I'm worried about not using the appropriate method and technique in mathematics. Matematik dersine uygun yöntem ve tekniği kullanamama endişesi yaşarım.

$7 \quad$ A rise in the level differences among my students while teaching mathematics worries me. Matematik dersini işlerken öğrencilerim arasında düzey farklılıklarının artmasından endişelenirim.

8 I am anxious since I believe that I do not have sufficient knowledge about teaching mathematics. Matematik öğretimine yönelik yeterli bilgiye sahip olmadığımı düşündüğümden endişelenirim.

9 When a student does not understand mathematical operations, I get anxious about how to explain them. Matematiksel işlemleri ögrenci anlamadı̆̆ında nasıl açıklayacă̆ım endişesi yaşarım.

10 I feel insecure about the thought that my students having level differences in mathematics can isolate themselves from the class eventually.

Matematik dersinde düzey farklılıkları olan öğrencilerimin zamanla kendilerini sinıftan soyutlayabilecekleri düşüncesi beni huzursuz eder.

11 I feel anxious that I cannot finish the outcomes of the mathematics curriculum on time. Matematik programındaki kazanımları zamanında bitiremeyeceğim endişesi yaşarım.

12 I am afraid that school administrators will criticize me if I cannot catch up with the mathematics curriculum.

Matematik programını yetiştiremezsem okul yöneticilerinin beni eleştirmesinden korkarım

13 I get anxious about designing activities that are appropriate for my students' level in mathematics. Matematik dersinde öğrencilerimin düzeyine uygun etkinlik hazırlama endişesi yaşarım.

14 I feel anxious while considering students' individual differences in teaching mathematics. Matematik ögrretirken bireysel farklılıklarl göz önünde bulundurma zorunluluğu beni endişelendirir.

15 I am afraid that families will criticize me if I cannot catch up with the mathematics curriculum. Matematik programını yetiştiremezsem ailelerin beni eleştirmesinden huzursuz olurum.

16 I'm worried about not enabling my students' to engage in mathematics actively. Öğrencilerimin matematik dersine aktif katılımını să̆layamama endişesi yaşarım.

17 I feel worry that I do not know how to teach mathematical concepts to students. Matematik kavramlarını kazandırırken nasıl öğreteceğimi bilmediğim için tedirgin olurum.

18 I feel fear of being humiliated by the students if I cannot solve problems in mathematics. Matematik dersinde problemleri çözemezsem ögrencilerin gözünde küçük düşmekten korkarım.

19 The thought that the level differences of the students in mathematics may reduce the interest of attending the lesson disturbs me.

Matematik dersinde öğrencilerin düzey farklılıklarının derse olan ilgiyi azaltacă̆ı düşüncesi beni rahatsiz eder. 